\title{
Irrigation water as a potential pre-harvest source of bacterial contamination of vegetables
}

BY

\author{
OLUWATOSIN A. IJABADENIYI ${ }^{1}$, ELNA M. BUYS ${ }^{1}$, LEGESSE K. DEBUSHO ${ }^{2}$ \\ AND MIKE VANDERLINDE ${ }^{2}$ \\ ${ }^{1}$ Department of Food Science, University of Pretoria, Lynnwood Road, Pretoria 0002, \\ South Africa \\ ${ }^{2}$ Department of Statistics, University of Pretoria, Lynnwood Road, Pretoria 0002, \\ South Africa
}

Corresponding author: OLUWATOSIN A. IJABADENIYI

Email: tosynolu@yahoo.com

\begin{abstract}
The aim of this research is to determine the bacteriological quality of the irrigation canal from Loskopdam, the two rivers that feed it and vegetables (broccoli and cauliflower) in Mpumalanga, South Africa and also to predict the presence of selected bacterial pathogens in irrigation water and on vegetables with logistic regression analysis. Water and vegetable samples were examined for the presence of total coliforms, faecal coliforms, Escherichia coli, Listeria monocytogenes, Salmonella sp., Enterococcus, Staphylococcus aureus, aerobic sporeformers, anaerobic sporeformers and aerobic colony counts were done. Apart from bacterial analysis, the following physico-chemical tests: temperature, $\mathrm{pH}$, turbidity and COD were determined in water samples. The average COD and turbidity in the two rivers and the canal were higher than WHO and SA water guidelines. Sampling and analyses were done for a period of 12 months. Levels of faecal coliforms and E. coli were higher than the WHO standard. S. aureus, Intestinal Enterococci, Salmonella, L. monocytogenes were recovered from the two rivers and the canal. Apart from L. monocytogenes which was not recovered from cauliflower, all bacterial pathogens recovered from the surface water were recovered from the vegetables.
\end{abstract}


Practical application: These results show that the rivers in Mpumalanga may contribute to the contamination in the irrigation canal which may be a possible preharvest source of contamination of broccoli and cauliflower, which may in turn constitute a health risk to consumers. Logistic regression analysis of the sampled data showed that COD was statistically reliable to predict L. monocytogenes, turbidity reliable to predict Intestinal Enterococci and faecal coliform and coliform reliable to predict Salmonella in irrigation water. Aerobic colony count (ACC) was statistically significant for the prediction of the three pathogens in vegetables.

Key words: River water, irrigation water, broccoli, cauliflower, bacterial pathogen, Logistic regression analysis

\section{Introduction}

Commercial and small-scale farmers generally irrigate their produce with water from nearby rivers, streams, ponds, wells and dams most of which do not meet the required standard for irrigation (Westcot, 1997, SAWQG, 1996). According to Sigge \& Fitchet (2009), $98 \%$ of South African water resources are fully utilized while $80 \%$ of her municipal sewerage systems are overburdened. These reasons make SA surface water a potential source of contamination of fresh.

Although the nutritional and other benefits of regular intake of fruits and vegetables are well documented (Lerici et al., 2000), internationally, risk has been associated with consumption of fresh fruit and vegetables (De Roever, 1998; Beuchat, 2002 ). In September 2006, pre-packaged fresh spinach was recalled by the Food and Drug Administration (FDA) in the United States of America (USA) as a result of an E. coli outbreak in California, USA (IFT, 2007).

Ibenyassine et al. (2006) and Steel et al. (2005) reported that contaminated irrigation water and surface run-off water may be major sources of pathogenic microorganisms that contaminate fruits and vegetables in fields. River water used for both human and animal waste disposal poses a health risk due to contamination with Salmonella and Listeria when used for irrigation of produce (Johnson et al., 1997, Combarro et al., 1997). Combarro et al. (1997) isolated different Listeria species from river water in Spain. It can be seen from the above that microbiological quality of irrigation water is 
paramount to the safety of fresh and minimally processed vegetables (Solomon et al., 2002; Bihn \& Gravani, 2006).

According to Ailes et al. 2008, improved diagnostic methods and food borne disease surveillance systems enhancements have helped in produce safety and vegetables recall. Another thing that may lead to improved produce safety is the use of other indicator organisms different from the common ones i.e., faecal coliforms, faecal streptoccoci and E. coli. Physico-chemical properties may also be used for monitoring the microbiological safety of water (Horman et al., 2004). Horman et al. 2004 found that together with E. coli and faecal coliform, Clostridium perfrigens could be used as indicator of water safety. Also, combination of suitable indicators such as coliform and acid-fast bacteria, coliphages, the standard plate count, and fecal streptococci has been recommended for adequate monitoring (Grabow et al., 1983). Infact, Harwood et al. 2005 believed that public health cannot be adequately protected through simple monitoring schemes based on the use of E. coli alone but suggested that additional parameters should be used as indicators. Scott et al. 2002 also confirmed that the use of other pathogens, chemical method, genotypic and phenotypic methods are fundamental to microbial source tracking.

We therefore seek to determine the effect of source water on the bacterial quality of water in the canal it feeds and also the subsequent contribution to the bacterial contamination of fresh vegetables during a 12 month sampling period in Mpumalanga, South Africa. Another goal of this work was to use logistic regression analysis to predict the presence of Salmonella spp, L. monocytogenes and intestinal Enterococcus in irrigation water and vegetables. Determination of Salmonella spp, $L$. monocytogenes and intestinal Enterococcus in irrigation water and vegetables could be costly and also time consuming. Although the use of logistic regression analysis for prediction in irrigation water and fresh produce is uncommon, Ailes et al. (2008) used this model to confirm that microbial concentrations on fresh produce are predicted by postharvest processing, importation and season. Also, the absence of some indicators in water was significant to predict its safety through logistic regression model (Horman et al., 2004). 


\section{Materials and methods}

\section{Selection of rivers and vegetables}

Due to various reports of contamination, the Loskop dam irrigation scheme in the Mpumaplanga Province of SA was selected as the sampling area for this study.

Surface water samples were collected from three points Loskop canal from which the farmers irrigate and two rivers that feed the Loskop dam, the Olifants and Wilge rivers. Water from the dam is subsequently released to Loskop canal system which is used to irrigate the vegetables. Surface water from the three points was aseptically collected during 12 intervals ( November 2007 to October 2008).

Three farms cultivating vegetables irrigated with water from the Loskop dam irrigation scheme were also visited three times over a period of 3 months for collection of vegetables, cauliflower and broccoli.

\section{Bacterial and physicochemical analyses of samples}

Water and vegetable samples were examined for the presence of total coliforms, faecal coliforms, E. coli, L. monocytogenes, Salmonella sp., Enterococcus, S. aureus, aerobic sporeformers (ASF), anaerobic sporeformers (AnSF) and aerobic colony counts (ACC) were done. Apart from bacterial analysis, the following physicochemical tests: temperature, $\mathrm{pH}$, rainfall, turbidity and chemical oxygen demand (COD) were determined in water samples.

\section{Aerobic colony counts}

Dilution series of water samples were prepared using BPW buffered peptone water (Oxoid Ltd; Basingstoke, Hampshire, England) and $0.1 \mathrm{ml}$ each of the dilutions were pour plated with Nutrient Agar (Oxoid) and incubated at $30{ }^{\circ} \mathrm{C}$ for $72 \mathrm{~h}$ (ISO, 1991).

\section{Aerobic and anaerobic sporeformers}

Water samples, $20 \mathrm{ml}$, were heated in a sterile test tube in a water bath $\left(75^{\circ} \mathrm{C}\right)$ for 20 min (Austin, 1998). Serial dilutions were pour plated. A set of plates were incubated aerobically at $37{ }^{\circ} \mathrm{C}$ for $48 \mathrm{~h}$ while the other set of plates were incubated anaerobically in an anaerobic jar with anaerocult (Merck Ltd; Wadeville, Gauteng, South Africa ) at $37{ }^{\circ} \mathrm{C}$ for $48 \mathrm{~h}$. 


\section{Coliforms and faecal coliforms}

Coliforms and faecal coliforms in the water samples were determined using the Most Probable Number (MPN) method (Christensen, et al., 2002).

\section{Escherichia coli}

Positive E. coli broth (MPN) samples were inoculated onto the surface of L-EMB (Oxoid) agar plates with inoculating loop and incubated at $37{ }^{\circ} \mathrm{C}$ for $24 \mathrm{~h}$ (Christensen, et al., 2002). Typical colonies from L-EMB were streaked onto E. coli chromogenic agar (Oxoid), thereafter colonies were confirmed with API 20E (Oxoid Ltd; Basingstoke, Hampshire, England).

\section{L. monocytogenes}

L. monocytogenes was determined according ISO, 2004. A $1 \mathrm{ml}$ water sample was added to $9 \mathrm{ml}$ of $1 / 2$ frazer broth (Oxoid) and it was incubated at $37{ }^{\circ} \mathrm{C}$ for $48 \mathrm{~h} .0 .1 \mathrm{ml}$ of the $1 / 2$ frazer broth culture was then transferred into a test tube containing $10 \mathrm{ml}$ of full frazer broth (Oxoid) and also incubated $37^{\circ} \mathrm{C}$ for $48 \mathrm{~h}$. Oxford Agar (Oxoid) plates and Palcam (Oxoid) agar plates were inoculated from culture from frazer broth. The plates were placed in an anaerobic jar and incubated microaerobically at $37{ }^{\circ} \mathrm{C}$ for $24 \mathrm{~h}$. Typical colonies were streaked onto Listeria chromogenic agar (Oxoid), thereafter colonies were confirmed with API Listeria (Oxoid).

\section{Salmonella}

Salmonella sp was determined according to ISO, 1993. A $25 \mathrm{ml}$ water sample was added to $225 \mathrm{ml}$ sterile BPW buffered peptone water and incubated $37{ }^{\circ} \mathrm{C}$ for $24 \mathrm{~h}$. The pre-enriched sample suspension, $10 \mathrm{ml}$, was transferred into $100 \mathrm{ml}$ of Selenite cystine medium (Oxoid) and incubated at $37{ }^{\circ} \mathrm{C}$ for $24 \mathrm{~h}$. About $0.1 \mathrm{ml}$ of the same pre- enriched sample suspension was transferred into $10 \mathrm{ml}$ of RVS (Merck Ltd; Wadeville, Gauteng, South Africa) and incubated at $37{ }^{\circ} \mathrm{C}$ for $24 \mathrm{~h}$. Phenol Red/Brilliant Green agar (Oxoid) and XLD (Oxoid) agar plates were inoculated with cultures from Selenite cystine and RVS medium. The plates were incubated at $37{ }^{\circ} \mathrm{C}$ for $24 \mathrm{~h}$. Typical colonies were streaked onto Salmonella chromogenic agar (Oxoid), thereafter colonies were confirmed with API 20E (Oxoid Ltd; Basingstoke, Hampshire, England). 


\section{S. aureus}

S. aureus was determined according to ISO, 1999. About $0.1 \mathrm{ml}$ each of the dilutions were released on Baird Parker (Oxoid) agar plates containing egg-yolk tellurite solution (Oxoid). Plates were incubated at $37{ }^{\circ} \mathrm{C}$ for $24 \mathrm{~h}$. Catalase test was performed on positive colonies and confirmed with Staphylase test (Oxoid Ltd; Basingstoke, Hampshire, England).

\section{Intestinal Enterococcus}

About $100 \mathrm{ml}$ of water samples was filtered through $0.45 \mu \mathrm{m}$ membrane filter and placed on Slanetz and Bartley medium (Oxoid) mixed with 2,3,5-triphenyltetrazolium chloride (Oxoid) after which plates were incubated at $37{ }^{\circ} \mathrm{C}$ for $44 \mathrm{~h}$ (ISO, 2000). Incubated $0.45 \mu \mathrm{m}$ membrane filter that gave presumptive positive colonies were transferred to the surface of Bile Aesculin Azide agar (Oxoid) and incubated at $44{ }^{\circ} \mathrm{C}$ for $2 \mathrm{~h}$. Typical intestinal Enterococci colonies gave a tan to black colour.

\section{Determination of physico-chemical parameters in surface water}

The $\mathrm{pH}$, rainfall, temperature, turbidity, chemical oxygen demand (COD) of the irrigation water was determined concurrently with the microbiological analysis. Temperature of the surface water was measured with Checktemp1 Portable digital thermometer (Hanna Instruments Inc. Woonsocket, R1, USA). pH was measured with 211 Microprocessor pH meter (Hanna Instruments Inc. Woonsocket, R1, USA) while turbidity was determined with H1 93703 Microprocessor turbidity meter (Hanna Instruments Inc. Woonsocket, R1, USA). Chemical Oxygen Demand (COD) was measured using the closed reflux colorimetric method, as described in standard methods (APHA, 2001). Rainfall however was obtained from a meteorological report.

\section{Statistical Analysis}

Analysis of variance (ANOVA), $\mathrm{p} \leq 0.05$, was used to determine whether there were significant differences between the levels of turbidity, COD, aerobic plate count, aerobic spore former counts and anaerobic spore former counts in water samples from the Olifants river, Wilge river and Loskop canal $(n=12)$ as well as between the bacterial counts determined on the cauliflower and broccoli from three farms and the Loskop-canal $(n=3)$. Statitica Version 9 (Statsoft, 1984- 2009) was used for the statistical analysis. 
The associations of the occurrence of Listeria monocytogenes, Salmonella spp and Intestinal Enterococcus in irrigation water and vegetables were explored using binary logistic regression analysis. For this analysis, we dichotomised the dependent variables, Listeria monocytogenes, Salmonella spp and Intestinal Enterococcus where values for absence were coded as ' 0 ' while values for presence were coded as ' 1 '. For prediction of the three bacterial pathogens in irrigation water, four predictor variables (i.e faecal coliform, location, COD and turbidiy) were taken into the model. On the other hand, ACC, S. aureus, location, AnSF and faecal coliform were used as predictor variables in the model for prediction of the bacterial pathogens in vegetables. The resulting regression coefficients quantified the type of association between the predictor variable and the respective dependent variable. A $p$-value of $\leq$ 0.05 was considered statistically significant and all reported $p$-values were two-tailed.

\section{Results}

Physico-chemical properties of water from Loskop-canal, Olifants river and Wilge river

The mean turbidity and COD of 36 samples taken Loskop-canal, Olifants and Wilge rivers were $20 \mathrm{NTU}$ and 55. $49 \mathrm{mg} / \mathrm{l}$ (Table 1). The mean turbidity level was higher than the international turbidity (1 NTU) standard for water; also mean COD was also higher than the international standard which is 10mg/l (DWAF, 1996a). However, sampling interval and sites had significant effect on the turbidity and COD (Table 1).

Incidence of aerobic bacteria, aerobic spore former bacteria (ASF) and anaerobic spore former bacteria (AnSF) in the Loskop-canal, Olifants river and Wilge river

There was no significant difference on the mean values of aerobic colony count in Loskop canal and the two rivers; Olifants and Wilge rivers during the 12 sampling intervals (Table 2). However, sampling interval and sites had significant effect (Table 
1). There were some intervals in which there were significant differences in the ACC results. The mean ACC of the 36 samples altogether was $3.02 \log { }_{10} \mathrm{cfu} / \mathrm{ml}$ (Table 1).

Unlike the mean values of the aerobic colony counts of water samples, there were significant differences on the mean values of aerobic spore formers and anaerobic spore formers recovered from Loskop canal and the two rivers; Olifants and Wilge rivers during the 12 sampling intervals (Table 2). The mean ASF and AnSF of the 36 samples altogether was 1.62 and $1.42 \log 10 \mathrm{cfu} / \mathrm{ml}$ respectively (Table 1).

Table 1 : Indicators and proportion of samples positive for various pathogens for 36 surface water samples collected between November 2007 and November 2008 in Mpumalanga South Africa

\begin{tabular}{|c|c|c|c|c|c|c|c|c|c|c|c|c|c|c|}
\hline & & & & & & & & & & & $\begin{array}{l}\% \% 0 \\
\text { path }\end{array}$ & $\begin{array}{l}\text { Imples } \\
\text { ens }\end{array}$ & ositiv & \\
\hline $\begin{array}{l}\text { Sampling } \\
\text { time }\end{array}$ & $\begin{array}{l}\text { No of } \\
\text { samples/sites }\end{array}$ & ${ }_{\mathrm{P}} \mathrm{H}$ & $\begin{array}{l}\text { Temp } \\
\left(\mathrm{O}^{\circ} \mathrm{C}\right)\end{array}$ & Turbidity $^{\mathbf{a}}$ & $\begin{array}{l}\text { Rain- } \\
\text { fall }\end{array}$ & $\begin{array}{l}\mathrm{COD}^{\mathrm{a}} \\
(\mathrm{mg} / \mathrm{l})\end{array}$ & $\mathrm{ACC}^{\mathrm{a}}$ & $\mathbf{A S F}^{\mathbf{a}}$ & AnSF $^{a}$ & $\begin{array}{l}S . \\
\text { aureus }^{b}\end{array}$ & $\begin{array}{l}E . \\
\text { coli }\end{array}$ & $\mathbf{L M}^{\mathbf{b}}$ & I.E $\mathbf{E}^{\mathrm{a}}$ & $\begin{array}{l}\underset{\text { Salmonella }}{\mathbf{s p}^{\mathrm{b}}} \\
\end{array}$ \\
\hline Nov 2007 & 3 & 8.40 & 16.50 & 9.58 & $\mathbf{0}$ & 59.90 & 3.98 & 1.45 & 1.36 & 0 & 100 & 0 & 100 & 0 \\
\hline Dec 2007 & 3 & 8.30 & 16.30 & 39.05 & $\mathbf{0}$ & 63.64 & 3.18 & 2.09 & 2.78 & $\mathbf{0}$ & 100 & 33 & 67 & 100 \\
\hline Jan 2008 & 3 & 7.55 & 18.80 & 16.08 & 0 & 49.71 & 2.07 & 2.49 & 1.88 & 0.72 & 100 & 100 & 100 & 100 \\
\hline Feb 2008 & 3 & 7.43 & 24.00 & 8.75 & $\mathbf{0}$ & 102.66 & 3.51 & 2.02 & 1.59 & 1.42 & 100 & 67 & 100 & 67 \\
\hline $\begin{array}{l}\text { March } \\
2008\end{array}$ & 3 & 7.23 & 17.60 & 31.6 & 0.5 & 66.19 & 3.47 & 2.25 & 2.18 & 0.59 & 100 & 33 & 33 & 67 \\
\hline April 2008 & 3 & 7.43 & 21.60 & 66.85 & $\mathbf{0}$ & 78.69 & 3.87 & 2.14 & 2.07 & 0.76 & 100 & $\mathbf{0}$ & 100 & $\mathbf{0}$ \\
\hline May 2008 & 3 & 7.22 & 16.4 & 26.59 & $\mathbf{0}$ & 93.59 & 3.68 & 1.54 & 2.23 & $\mathbf{0}$ & 100 & $\mathbf{0}$ & 100 & $\mathbf{0}$ \\
\hline July 2008 & 3 & 7.37 & 10.50 & 5.00 & $\mathbf{0}$ & 42.80 & 2.44 & 0.51 & 0.91 & 0.19 & 100 & 100 & 67 & $\mathbf{0}$ \\
\hline Aug. 2008 & 3 & 7.03 & 13.90 & 6.35 & $\mathbf{0}$ & 15.64 & 1.98 & 1.17 & 0.44 & 0.13 & 100 & 100 & 67 & 33 \\
\hline Sept. 2008 & 3 & 7.26 & 19.90 & 6.56 & $\mathbf{0}$ & 38.50 & 2.59 & 1.23 & 0.52 & 0.38 & 100 & 100 & 100 & $\mathbf{0}$ \\
\hline Oct. 2008 & 3 & 7.28 & 23.20 & 5.78 & $\mathbf{0}$ & 20.50 & 2.64 & 0.85 & 0.75 & 0.07 & 100 & 100 & 100 & 33 \\
\hline Nov 2008 & 3 & 7.27 & 25.30 & 17.78 & 2 & 34.11 & 2.86 & 1.72 & 0.33 & 0.26 & 100 & $\mathbf{0}$ & 33 & 100 \\
\hline Total & 36 & 7.48 & 18.67 & 20.00 & 0.21 & 55.49 & 3.02 & 1.62 & 1.42 & 0.40 & 100 & 53 & 81 & 42 \\
\hline
\end{tabular}

${ }^{\text {a }}$ The $P$ value for the effect of sampling interval and sampling site is $<0.05$ as determined by ANOVA

${ }^{\mathrm{b}}$ The $\mathrm{P}$ value for the effect of sampling interval is $<0.05$ while the sampling site is $>0.05$ as determined by ANOVA

Key: COD, Chemical Oxygen Demand; ACC, Aerobic Colony Count; ASF, Aerobic Spore Formers; AnSF, Anaerobic Spore Formers; LM, L. Monocytogenes; I. E, intestinal Enteroccocus

Prevalence of $S$. aureus, $E$. coli, Intestinal Enterococcus, Salmonella and $L$. monocytogenes in water from three surface water during the 12 sampling intervals.

The mean \% of samples positive for L. monocytogenes from the total 36 samples was $53 \%$. While it was $81 \%$ for Intestinal Enterococcus and $42 \%$ for Salmonella sp (Table 1). 
Of the water samples collected during the 12 sampling intervals, $25 \%$ of the samples from the Olifants river, $33 \%$ from the Wilge river and $58 \%$ of the samples from Loskop canal were positive for $S$. aureus (Fig 1). However the mean S. aureus counts of water from the three surface water sampling sites was very low $<1 \log _{10} \mathrm{cfu} / \mathrm{ml}$ (Table 2).

Table 2: Mean counts $\left(\log _{10} \mathrm{cfu} / \mathrm{ml}\right)$ of ACC, aerobic spore formers, anaerobic spore formers and $S$. aureus recovered from Loskop canal, Olifants river and Wilge river during 12 intervals

\begin{tabular}{|l|l|c|c|c|}
\hline Sampling site & \multicolumn{1}{|c|}{ ACC } & ASF & AnSF & S. aureus \\
\hline Loskop canal & $2.96^{\mathrm{a}}$ & $1.33^{\mathrm{a}}$ & $1.33^{\mathrm{ab}}$ & $0.46^{\mathrm{a}}$ \\
\hline Olifants river & $3.04^{\mathrm{a}}$ & $1.59^{\mathrm{ab}}$ & $1.13^{\mathrm{a}}$ & $0.32^{\mathrm{a}}$ \\
\hline Wilge river & $3.06^{\mathrm{a}}$ & $1.91^{\mathrm{b}}$ & $1.74^{\mathrm{b}}$ & $0.31^{\mathrm{a}}$ \\
\hline
\end{tabular}

Means with the same letter are not significantly different.

E. coli (confirmed with API E20) was recovered from the two rivers and Loskop canal during every sampling interval (Fig 1). Furthermore coliform and faecal coliform levels for the surface water met the international standard (1000 MPN/100ml) only once during the 12 sampling intervals in Loskop canal water while at the Wilge and Olifants rivers, the water samples met the standard during $25 \%$ and $30 \%$ of the 12 sampling intervals respectively.

Intestinal Enterococcus was present in all the water samples collected from the Wilge river while incidence was lower in the the Olifants river (67\%) and Loskop canal (75 \%) (Fig 1). Incidence of Salmonella (50 \%) was highest in Loskop canal than in Wilge river and Olifants (33\% and $42 \%$ respectively), however the incidence of $L$. monocytogenes (58\%) in Wilge river was higher than the $50 \%$ incidence observed in both Loskop canal and Olifants during the 12 sampling intervals (Fig 1). 


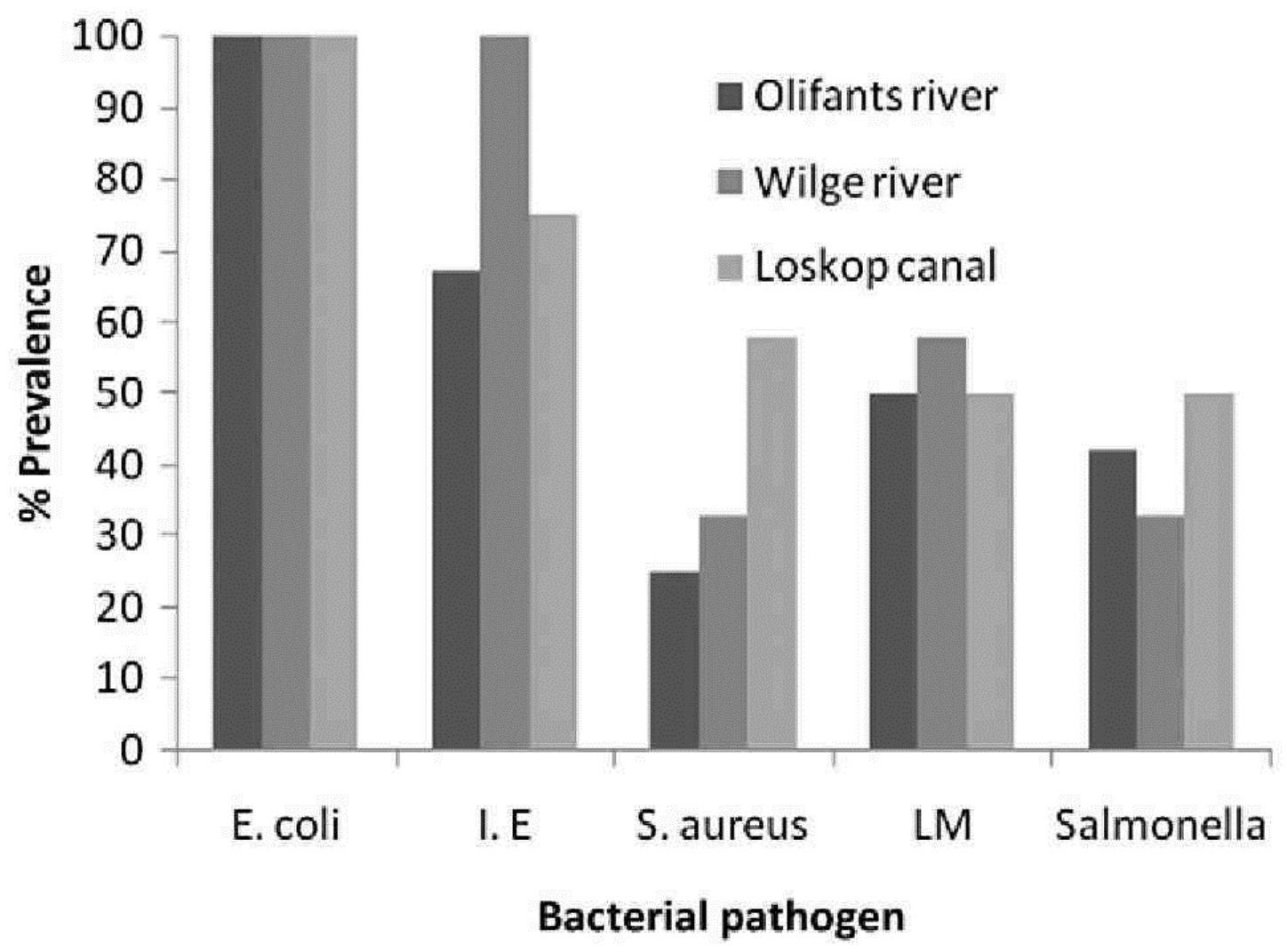

FIG. 1. PREVALENCE OF BACTERIAL PATHOGENS IN THE THREE WATER SOURCES DURING 12 SAMPLING INTERVALS

Bar 1 = Olifants rive; bar 2 =Wilge river; bar $3=$ Loskop canal.

Incidence of aerobic bacteria, aerobic spore bacteria and anaerobic spore bacteria on broccoli and cauliflower

The average ACC on cauliflower was $3.8 \log _{10} \mathrm{cfu} / \mathrm{g}$ while it was $4.1 \log _{10} \mathrm{cfu} / \mathrm{g}$ on broccoli. Similarly, the average ASF and AnSF were also higher on broccoli. ASF on broccoli and cauliflower were $2 \log _{10} \mathrm{cfu} / \mathrm{g}$ and $1.5 \log _{10} \mathrm{cfu} / \mathrm{g}$ respectively while AnSF on broccoli and cauliflower were $1.6 \quad \log _{10} \quad \mathrm{cfu} / \mathrm{g}$ and $1.4 \log _{10} \mathrm{cfu} / \mathrm{g}$ respectively. There was no significant difference between the mean aerobic bacteria count of broccoli and cauliflower from the three farms whereas the mean anaerobic spore counts and aerobic spore counts differed significantly $(\mathrm{P} \leq 0.05)$ (Table 3$)$. However, there was significant difference in aerobic colony count, aerobic spore counts and anaerobic spore counts in the two vegetables from the individual farm (Table 3). 
Table 3: Analysis of variance for ACC, ASF, and AnSF of broccoli, cauliflower and irrigation water from the Loskop- canal at 3 intervals for a period of three months

\begin{tabular}{|l|c|c|c|c|}
\hline Effect & $\begin{array}{l}\text { Degrees of } \\
\text { freedom }\end{array}$ & ACC & ASF & AnSF \\
\hline $\begin{array}{l}\text { Sampling } \\
\text { interval }\end{array}$ & 2 & 0.266 & 0.001 & 0.002 \\
\hline Source & 2 & 0.001 & 0.003 & 0.024 \\
\hline $\begin{array}{l}\text { Sampling } \\
\text { interval and } \\
\text { source }\end{array}$ & 4 & 0.001 & 0.001 & 0.101 \\
\hline
\end{tabular}

Statistical significance of main factor and interaction: $p \leq 0.05$

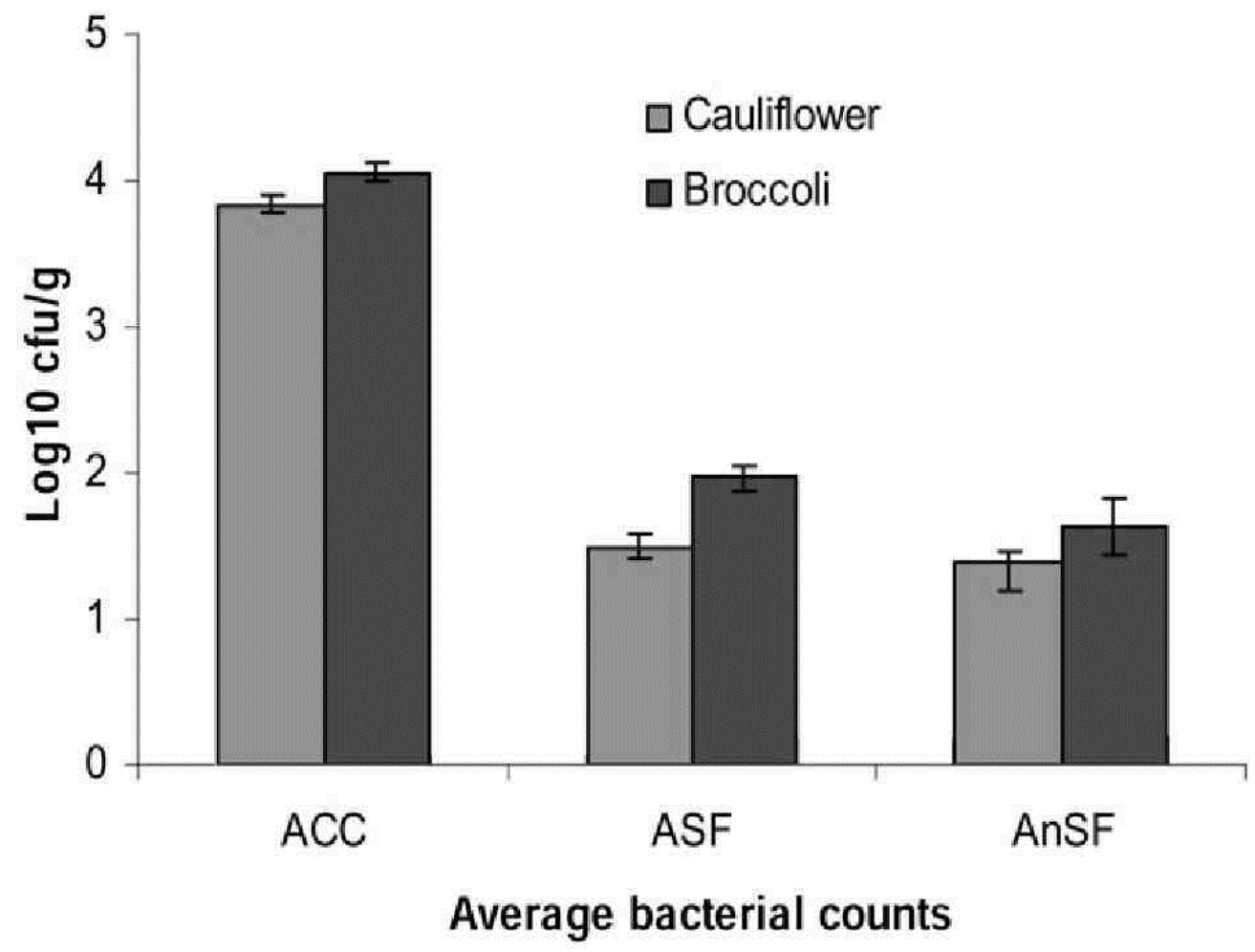

FIG. 2. THE AVERAGE ACC, ASF AND ANSF ON BROCCOLI AND CAULIFLOWER DURING THREE SAMPLING INTERVALS

Bar 1 = cauliflower; bar 2 = broccoli. 
The average ACC in the three water samples from the Loskop canal, Wilge and Olifants rivers was lower than that on the two vegetables however the average ASF and AnSF were almost the same i.e., $\leq 0.2$. Average APC, ASF and AnSF in the water samples were 3.0, 1.6, $1.4 \log 10 \mathrm{cfu} / \mathrm{ml}$ (Table 1) while they were 3.9, 1.8 and $1.5 \log _{10} \mathrm{cfu} / \mathrm{g}$ respectively on vegetables (Fig. 2).

Incidence of S. aureus, E. coli, Intestinal Enteroccoci (I. E), Salmonella and L. monocytogenes (LM) on cauliflower, and broccoli

Incidence of $S$. aureus on broccoli (67\%) was higher than on the cauliflower (33\%). However, the average $S$. aureus counts on the vegetables during the three month sampling period was very low $<1 \log _{10} \mathrm{cfu} / \mathrm{ml}$ (Fig. 3).

E. coli was recovered from Loskop canal, cauliflower and broccoli during the three sampling intervals (Fig. 3). Incidence of Intestinal Enterococcus on broccoli was higher than that on cauliflower. The incidence was 44 and $33 \%$ respectively, it was however $67 \%$ in Loskop canal. Also, the incidence of Salmonella (33\%) in Loskop canal was higher than the $11 \%$ incidence observed on broccoli and cauliflower (Fig. Fig 3). Only broccoli was positive for L. monocytogenes during the three sampling intervals however L. monocytogenes were recovered from Loskop canal at other sampling intervals when vegetables were not examined. Also, with an exception of $L$. monocytogenes which was not recovered from cauliflower, all the bacterial pathogens isolated from the three water sources were also isolated from the two vegetables.

\section{Predictive relationships between predictors}

A pooled data set from Loskop canal, Olifants river and Wilge river were analysed to determine if the concentrations of any of the indicators, total coliforms, faecal 


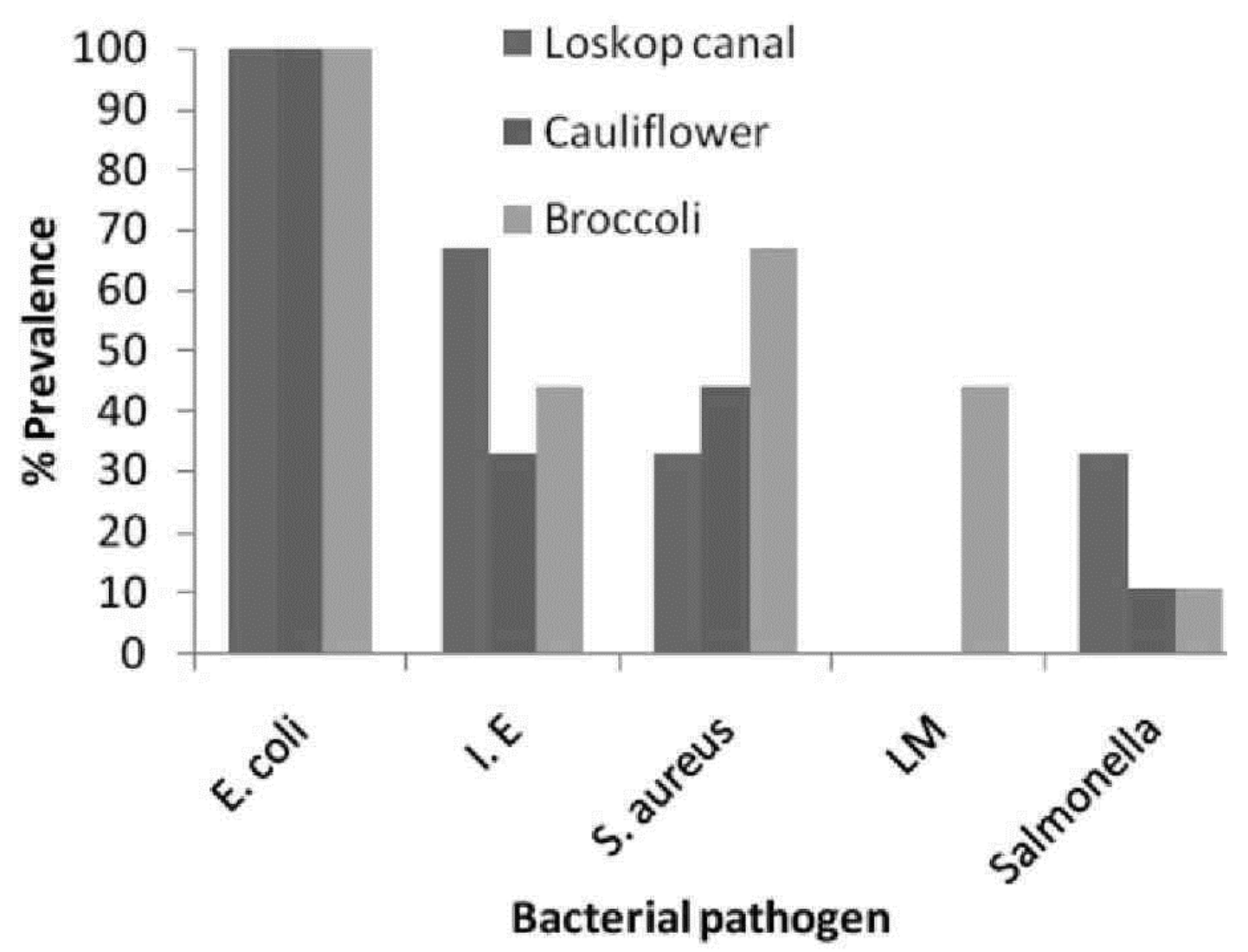

FIG. 3. PREVALENCE OF BACTERIAL PATHOGENS IN THE LOSKOP CANAL AND THE TWO VEGETABLES DURING THREE SAMPLING INTERVALS

Bar 1 = Loskop canal; bar 2 = cauliflower; bar 3 = broccoli.

coliforms, S. aureus, aerobic sporeformers, anaerobic sporeformers and aerobic colony counts, were correlated with each other and with physico-chemical parameters (turbidity and chemical oxygen demand). High significant correlations were observed between faecal coliforms and total coliforms ( $r=0.999 ; p-$ value $<0.0001)$, aerobic sporeformers and anaerobic sporeformers $(r=0.535 ; p-$ value $<0.0001), S$. aureus, aerobic sporeformers $(r=0.498 ; p$-value $<0.0001)$, aerobic colony counts and anaerobic sporeformers $(r=0.354 ; p-v a l u e=0.0002)$, aerobic colony counts and S. aureus ( $r=0.345 ; p$-value $=0.0003)$; and a significant correlation was observed between anaerobic sporeformers and $S$. aureus $(r=0.203 ; p$-value $=0.0354)$. Except between turbidity and $S$. aureus, chemical oxygen demand and total coliforms, chemical oxygen demand and faecal coliforms; significant correlations were observed 
between the concentrations of any of the indicators with physico-chemical parameters.

Binary logistic regression was used to test the hypothesis that faecal coliform, location, COD and turbidity were predictive of the presence of L. monocytogenes, Salmonella spp and Intestinal Enterococcus in irrigation water. Binary logistic regression was also used to test the hypothesis that ACC, ASF, AnSF, S. aureus, faecal coliforms and coliforms were predictive of the presence of $L$. monocytogenes, Salmonella spp and Intestinal Enterococcus on vegetables.

Table 4: Prediction of LM, IE and Salmonella in irrigation water with Logistic regression analysis

\begin{tabular}{|l|l|l|l|}
\hline Predictors & $\hat{\beta}$ & Wald & p-value \\
\hline LM & -0.0014 & 0.5785 & \\
Feacal & 0.0001 & 0.5194 & 0.4469 \\
Coliform & -0.0199 & 0.6958 & 0.4711 \\
Curbidity & -0.0399 & 9.4825 & 0.4042 \\
IE & & & 0.0021 \\
Feacal & & & \\
Coliform & 0.0013 & 0.4224 & 0.5157 \\
Turbidity & -0.0001 & 5.7643 & 0.5505 \\
COD & -0.0544 & 2.4581 & 0.0164 \\
Salmonella & 0.0264 & & 0.1169 \\
Feacal & & 3.864 & \\
Coliform & 0.0048 & 3.8038 & 0.0500 \\
Turbidity & -0.0005 & 0.3399 & 0.0500 \\
COD & 0.0105 & & \\
\hline A & & & \\
\hline
\end{tabular}

A p-value of $\leq 0.05$ was considered statistically significant 
Table 5: Prediction of LM, IE and Salmonella in vegetables with Logistic regression analysis

\begin{tabular}{|c|c|c|c|}
\hline Predictors & $\hat{\beta}$ & Wald & $\mathrm{p}$-value \\
\hline \multicolumn{4}{|l|}{ LM } \\
\hline $\mathrm{ACC}$ & -1.8486 & 17.9433 & 0.0001 \\
\hline ASF & -0.2353 & 0.3620 & 0.5474 \\
\hline AnSF & -0.0767 & 0.0586 & 0.8088 \\
\hline S. aureus & 0.9414 & 6.9747 & 0.0083 \\
\hline Feacal & -0.0004 & 0.0855 & 0.7700 \\
\hline Coliform & 0.0001 & 0.0830 & 0.7733 \\
\hline \multicolumn{4}{|l|}{ IE } \\
\hline $\mathrm{ACC}$ & -0.7971 & 6.2123 & 0.0127 \\
\hline ASF & 0.0152 & 0.0016 & 0.9682 \\
\hline AnSF & 0.7324 & 5.2992 & 0.0213 \\
\hline S. aureus & -0.1662 & 0.2770 & 0.5986 \\
\hline Feacal & -0.0020 & 3.1176 & 0.0775 \\
\hline Coliform & 0.0002 & 3.3093 & 0.0689 \\
\hline \multicolumn{4}{|c|}{ Salmonella } \\
\hline ACC & -1.2487 & 9.7924 & 0.0018 \\
\hline ASF & 0.1181 & 0.0932 & 0.7602 \\
\hline AnSF & 0.6926 & 4.2584 & 0.0391 \\
\hline S. aureus & 0.5469 & 2.4546 & 0.1172 \\
\hline Feacal & 0.0007 & 0.3020 & 0.5827 \\
\hline Coliform & -0.0001 & 0.2633 & 0.6079 \\
\hline
\end{tabular}

A p-value of $\leq 0.05$ was considered statistically significant 
Prediction of Listeria monocytogenes, Salmonella spp and Intestinal Enterococcus in water samples from Loskop canal, Wilge rivers and Olifants river

Results of logistic regression indicated that only one predictor, COD, was statistically reliable $(\mathrm{p} \leq 0.05)$ to predict the presence $L$. monocytogenes. Turbidity was found to be statistically significant $(\mathrm{p} \leq 0.05)$ to predict the presence of Intestinal Enterococcus while faecal coliforms and coliforms however were found to be significant $(\mathrm{p} \leq 0.05)$ to predict the presence of Salmonella in the water samples from three sources. The estimates of regression coefficients of the predictors $\hat{\beta}$, Wald statistic and p-values are presented in Table 4.

Prediction of L. monocytogenes, Salmonella spp and Intestinal Enterococcus on vegetables

The result of logistic regression analysis shows that two predictors, ACC and $S$. aureus were statistically dependable $(\mathrm{p} \leq 0.05)$ to predict the presence $L$. monocytogenes on vegetables. Also, from the result of the logistic regression analysis, ACC and AnSF were observed to be significant $(\mathrm{p} \leq 0.05)$ to predict the presence of Intestinal Enteroccocus and Salmonella respectively. The estimates of regression coefficients of the predictors $\hat{\beta}$, Wald statistic and $\mathrm{p}$-values are also shown in Table 5.

\section{Discussion}

The temperature and $\mathrm{pH}$ values of the Loskop canal and the two rivers which were conducive for bacterial growth may have influenced the survival of indigenous and bacterial pathogens in the water sources. According to Pantshwa et al. (2009), these two parameters could influence the level of faecal coliforms and intestinal enterococci. The turbidity of the three water samples did not meet the SA water quality range for domestic water supply, 0 to 1 NTU (DWAF, 1996a), the turbidity range for water of good quality should be between 0 to 1 NTU. The high turbidity level of surface water in this work corresponds with the river turbidity result of Fatoki et al., (2003). Fatoki et al., (2003) who also found high turbidity levels in surface water indicated that soil erosion and run-off could be source of high turbidity in the 
water system (Fatoki et al., 2003). The soil erosion and run off could have been caused by the informal settlement around the two rivers. The COD results for all the three water samples from Loskopdam, Olifants river and Wilge river also did not meet the WHO standard of $10 \mathrm{mg} /$ litre. This shows that the surface water contains organic pollutants which may have originated from the informal settlements and mines around the region where rivers are located.

Although level of aerobic bacteria in both water and vegetable samples was low, high prevalence of bacterial pathogens was observed in this study. This shows that aerobic bacteria levels are not a good determinant of microbiological quality of irrigation water and produce.

The recovery of aerobic spore formers from the three water samples is similar to the work of Fournnelle, 1967 who recovered them from Alaska water at the same low level. The level of anaerobic spore formers observed in our water samples was however lower than has been reported by Molongoski \& Klug (1976). Molongoski \& Klug (1976) recovered up to $6 \log$ of anaerobic spore formers from fresh water lakes. Although low aerobic spore formers level was observed in the water samples, it may not be suitable for irrigation of fresh produce because of the possibility of microbial growth and cell division after attachment and infiltration on the vegetables.

Recovery of $S$. aureus from water samples is low. S. aureus was not expected to be recovered from Loskop- canal, Wilge river and Olifants river because its natural habitat is nasal cavity (Jay, 2000). The presence of $S$. aureus in the two rivers and Loskop- canal also show that the rivers may have contributed to the contamination level in the canal.

The result of heavy contamination of the three water sources, with E. coli and faecal coliform shows that the concern regarding contamination of surface water sources in SA may be valid and widespread. The two rivers may have been polluted with human feaces since E. coli and faecal coliform are indicators of faecal pollution (Garcia \& Servais, 2007; Pantshwa et al., 2009).

Contamination of water sources with other bacterial pathogens i.e L. monocytogenes and Salmonella show that the two rivers and canal are of poor microbiological quality 
and may be as a result of faecal pollution. It also indicates that the two rivers are potential sources of contamination of the Loskop-canal. Other workers have reported the widespread contamination of faecal polluted surface water with these pathogens and this is a public health concern especially when water is used for agricultural purposes (Lyautey et al., 2007; Garcia \& Servais, 2007). According to Bhagwat, (2006) the greatest concerns with human pathogens on fresh and minimally processed vegetables are E. coli $0157: \mathrm{H} 7$, Salmonella and L. monocytogenes. The first two have low infective doses while L. monocytogenes grow very well under refrigeration storage conditions (Bhagwat, 2006). Other safety concern with these pathogens is that they can form biofilms on the produce thereby making sanitizers' ineffective (Fonseca, 2006).

Although the Loskop canal may be a potential source of broccoli and cauliflower of food pathogens, the incidence of the pathogens on the two vegetables did not correspond. Lower incidence of $S$. aureus, Salmonella, Intestinal Enterococi and absence of Listeria monocytogenes on cauliflower compared to broccoli show the possibility of differences in surface characteristics of the two produce affecting pathogen attachment and survival (Fonseca, 2006; Ukuku et al., 2005 ). Broccoli among some other vegetables has been reported to pose a higher risk of being associated with listeriosis because of enhanced L. monocytogenes attachment (US FDA/CFSAN, 2008).

The result of the prediction of LM in irrigation water signifies that there is direct relationship between Listeria monocytogenes and COD in irrigation water. Higher COD results in water may result in high concentration of LM in irrigation water. The result also signifies that there is direct relationship between Intestinal Enteroccocus and turbidity. The reason why COD could not predict the presence of IE or turbidity predicting LM is not well understood yet.

Faecal coliform and coliforms have long been known as indicator of enteric bacteria in water generally (Jay, 2000). The logistic regression result proved that faecal coliform and coliform that can be used to predict the presence of Salmonella in water and that there is relationship between faecal coliform and Salmonella. This is similar to the observation of Polo et al. (1998) who showed that there is a direct relationship 
between the presence of Salmonella and indicators of faecal pollution i.e., coliforms and faecal coliforms in rivers, fresh water reservoirs and sea water. Ferguson et al., 1996 also observed that the higher the concentration of faecal coliform, the higher the recovery of Salmonella spp in aquatic habitat

The reason why faecal coliforms and coliforms were not significantly associated with LM and Intestinal Enterococcus may be because they are not usually found in human faeces unlike Salmonella. According to Gildreich \& Kenner, 1969 and Pantshwa et al., 2009, human faeces contain higher faecal coliforms counts, while animal faeces contain higher levels of faecal enterococci. Wild birds and animals have also been shown to be the main source of contamination with $L$ monocytogenes (Weiss \& Seeliger, 1975).

The study clearly indicates the potential effect of contaminated surface water (i.e River water) on irrigation water sources and pre-harvest vegetables. Also, logistic regression analysis may therefore be used as a tool for predictive microbiology model which has an immediate practical application to predict microbial produce safety and quality, and provide quantitative understanding of the microbial ecology of irrigation water and produce (Ross et al., 2000)

\section{Conclusion}

The water used for irrigation in our study is a likely source of contamination of broccoli and cauliflower with bacterial pathogens and it constitutes a food safety risk. The water should be properly treated when used for produce that may be eaten raw. This safety measure should be combined with Good Agricultural Practices (GAP) during production of fresh vegetables. Also, faecal coliforms and coliforms can be used to indicate high probability of Salmonella presence in water and they may be used as risk parameters. There is relationship between physiochemical properties of water i.e., COD and turbidity and certain bacterial pathogen i.e., L. monocytogenes and Intestinal Enterococcus. Low aerobic colony counts however can be used to indicate high probability of L. monocytogenes, Intestinal Enterococcus and Salmonella on vegetables. 
Acknowledgement to WRC for funding and bursaries must be included: This study was part of an ongoing solicited research project (K5/1773) funded by the Water Research Commission and co-funded with the Department of Agriculture

\section{References}

Ailes, E. C., Leon, J. S., Jaykus, L., Johnston, L. M., Clayton, H. A., Blanding, S., Kleinbaum, D. G., Backer, L. C. \& Moe, C. L. (2008). Microbial concentrations on fresh produce are affected by postharvest processing, importation and season. Journal of Food Protection 71, 2389- 2397

APHA (2001). Standard methods for the examination of water and wastewater. $20^{\text {th }}$ edition. Washington DC. $17 \mathrm{pp}$

Austin, J. W., (1998). Determination of aerobic and anaerobic sporeformers. Polyscience Publications. Quebec Canada. Pg 1- 6

Beuchat, L. R., (2002). Ecological factors influencing survival and growth of human pathogens on raw fruits and vegetables. Microbes and Infection 4, 413- 423

Bhagwat, A. A., (2006). Microbiological safety of fresh-cut produce: Where are we now? In microbiology of fresh produce. Edited by Matthews, K. R. ASM Press, Washington, DC.pg 121- 165

Bihn, E. A. \& Gravani, R. B., (2006). Role of good agricultural practices in fruit and vegetable safety. In microbiology of fresh produce. Edited by Matthews, K. R. ASM Press, Washington, DC. pg 21- 53

Christensen, D., Crawford, C. \& Szabo, R., (2002). Enumeration of coliforms, faecal coliforms and E. coli in foods using the MPN methods. http://www. hc-sc.gc.ca/foodaliment. Accessed 14 June 2007

Combarro, M. P., Gonzalez, M., Aranjo, M., Amezaga, A. C., Sueiro, R. A. \& Garrido, M. J., (1997). Listeria species incidence and characterisation in a river 
receiving town sewage from a sewage treatment plant. Water Science Technology 35, 201- 204

Department of Water Affairs and Forestry (DWAF). 1996 (a). South African water quality guidelines for domestic water use. Volume 1. $2^{\text {nd }}$ ed. Pretoria, South Africa

De Roever, C., (1998). Microbiological safety evaluations and recommendations on fresh produce. Food Control 9, 321-347

Fatoki, O. S., Gogwana, P., Ogunfowokan, A.O., (2003). Pollution assessment in the Keiskamma river and in the impoundment downstream. Water SA 29, 183- 187

FDA/CFSAN.,( 2008). Draft compliance policy guide on Listeria monocytogenes in ready-to-eat (RTE) foods . www.fda.gov/OHRMS/DOCKETS/98fr/FDA-2008-D0058-GDL.pdf. Accessed 20 March, 2008

Fergusson, C. M., Coote, B. G., Aahbolt, N. J. \& Stevenson, M. I., (1996). Relationship between indicators, pathogens and water quality in an estuarine system. Water Research 30, 2045-2054

Fonseca, J. M., (2006). Postharvest handling and processing: Sources of microorganisms and impact of sanitizing procedures. In microbiology of fresh produce. Edited by Matthews, K. R. ASM Press, Washington, DC. Pg 85- 120

Fournnelle, H. J., (1967). Soil and water bacteria in the Alaska subarctic tunda water. www.pubs.aina.ucalgary.ca. Accessed 25 June, 2009

Garcia, A. T. \& Servais, P., (2007). Respective condition of point and non-point sources of E. coli and Enterococci in a large urbanized watershed (the Seine river, France). Journal of Environmental Management 82, 512- 518

Gildreich, E. E. \& Kenner, B. A., (1969). Concepts of feacal streptococci in stream pollution. Journal of Water Pollution: Control Feeding 41, 336-352 
Grabow, W. K., Mullar-Gauss, v, Prozesky, O. W \& Deinhardt, F (1983). Inactivation of Hepatitis A Virus and indicator organisms in water by free chlorine residuals. Applied and Environmental Microbiology 46, 619- 624

Harwood, V. J., Levine, A. D, Scott, T. M, Chivukula, Lukasik, J, Farrah, S. R \& Roses, J. B., (2005). Validity of the indicator organism paradigm for pathogen reduction in reclaimed water and public health protection. Applied and Environmental Microbiology 71, 3163-3170

Horman, A., Rimhanen-Finne, R, Maunula, L, von Bonsdorff, C, Torvela, N, Heikinheimo, A \& Hanninen, M., (2004). Campylobacter spp., Giardia spp., Cryptosporidium spp., noroviruses, and indicator organisms in surface water in southwestern Finland, 2000-2001. Applied and Environmental Microbiology 70, 87-95

Ibenyassine, K., Aitmhand, R., Karamoko, Y., Cohen, N. \& Ennaji, M. M., (2006). Use of repetitive DNA sequences to determine the persistence of enteropathogenic Escherichia coli in vegetables and in soil grown in fields treated with contacted irrigation water. Letters in Applied Microbiology 43, 528- 533

IFT (2007). Food forecast 2007. Institute of Food Technologists. http://www.ift.org/cms/?pid=1001537\&printable=1. Accessed 4 April, 2007

ISO (1991). International Organisation for Standardization. General guidance for the enumeration of microorganisms. Case Postale 56. CH-1211 Geneva. Switzerland. Pg $1-5$

ISO (1993). International Organisation for Standardization. General guidance on methods for the detection of Salmonella. Case Postale 56. CH-1211 Geneva 20. Switzerland. Pg 1- 16

ISO (1999). International Organisation for Standardization. Horizontal method for the enumeration of coagulase- positive Staphylococci. Case Postale 56. CH-1211 Geneva. Switzerland. Pg 1- 15 
ISO (2000). International Organisation for Standardization. Detection and enumeration of intestinal enterococci. Case Postale 56. CH-1211 Geneva. Switzerland. Pg 1- 11

ISO (2004). International Organisation for Standardization. Horizontal method for the detection and enumeration of Listeria monocytogenes. Case Postale 56. CH-1211 Geneve 20. Switzerland. Pg 1- 13

Jay, J. M., (2000). Modern food microbiology. 6th Edition. Gaithersburg, Maryland: Aspen Publishers. 679 pp

Johnson, D. C., Enriquez, C. E., Pepper, I. L, Davis, T. L, Gerba, C. P \& Rose, J. B., (1997). Survival of Giardia, Cryptosporidium, poliovirus and Salmonella in marine waters. Water Science Technology 35, 261- 268

Lerici, C. R., Nicoli, M. C. \& Anese, M., (2000). The "weight given" to food processing at the Food and Cancer prevention 111 Symposium. Italian Journal of Food Science 12, 3-7

Lyautey, E., Lapen, D. R., Wilkes, G., Mccleary, K., Pagotto, F., Tyler, K., Hartmann, A., Piveteau, P., Rieu, A., Robertson, W. J., Medeiros, D. T., Edge, T. A., Gannon, V. \& Topp, E., (2007). Distribution and characteristics of Listeria monocytogenes isolates from surface waters of the South Nation River watershed, Ontario, Canada. Applied and Environmental Microbiology 73, 5401-5410

Molongoski, J. J \& Klug, M. J., (1976). Characterization of anaerobic heterotrophic bacteria isolated from freshwater lake sediments. Applied Environmental Microbiology 31, 83- 90

Pautshwa, M. J., van der Walt, A.M., Cilliers, S. S. \& Bezuidenhont, C. C., (2009). Investigation of faecal pollution and occurrence of antibiotic resistant bacteria in the Mooi river system as a function of a changed environment. www.ewisa. co.za/literature/files/2008_137.pdf. Accessed 13 August 2009 
Polo, F., Figueras, M. J., Laza, I., Sala, J., Flesher, J. M. \& Guarro, J (1998). Relationship between presence of Salmonella and indicators of faecal pollution in aquatic habitats. FEMS Microbiology Letters 160, 253-256

Ross, T., Dalgaard, P. \& Tienungoon, S., (2000). Predictive modelling of the growth and survival of Listeria in fishery products. International Journal of Food Microbiology 62, 231-245

Sadovski, A. Y., Fattal, B., Goldberg, D., Katzenelson, E. \& Shuval, H. I., (1978). High levels of microbial contamination of vegetables irrigated with waste water by the drip method. Applied Environmental Microbiology 36, 824-830

SAWQG .South African Water Quality Guidelines., (1996). Agricultural Water Use: Irrigation. 2nd Edition. pp 180

Scott, T. M., Rose, J. B, Jenkins, T. M, Farrah, S. R \& Lukasik, J (2002). Microbial source tracking: current methodology and future directions. Applied and Environmental Microbiology 68, 5796-5803

Sigge, G. \&. Fitchet, T., (2009). Food Safety in the limelight. South African Food Review 36, 14- 16

Solomon, E. B., Potenski, C. J. \& Matthews, K. R., (2002). Effect of irrigation method on transmission to and perstitence of Escherichia coli 0157:H7 on lettuce. Journal of Food Protection 65, 673-676

Steel, M., Mahdi, A. \& Odumeru, J., (2005). Microbial assessment of irrigation water used for production of fruit and vegetables in Ontario, Canada. Journal of Food Protection 68, 1388-1392

Ukuku, D. O., Liao, C. H. \& Gembeh, S., (2005). Attachment of bacterial human pathogens on fruit and vegetable surfaces.

Http://wyndmoor.arserrc.gov/page/2004\%5c7486.pdf. Accessed 8 June, 2009 
Weiss, J. \& Seeliger, H.P., (1975). Incidence of Listeria monocytogenes in nature. Applied Microbiology 29, 29-32

Westcot, D. W., (1997). Quality control of wastewater for irrigated crop production. Food Agricultural Organization. Water Reports no. 10. Rome: FAO, 86pp 